\section{秋田大学八郎潟研究委員会・半田市太郎篇 :} 八郎渴一一拓と社会変動-XIII, 611, 写真 7, 付図 1, 図並表多数, $25 \times 18 \mathrm{~cm}$, 東京, 創文社, 1968. $¥ 8,000$.

7 人の協力により, 多年の研究成果として出た巨 大冊である.八郎潟の干拓という大事業が完成し, さらに中央干拓地にモデル農村大潟村の創設が行わ れるというこの注目すべき事態は何人にとっても大 きな関心をひくことである. 地元の秋田大学の研究 者にとっては殊の外研究心をそそる問題であると共 に,この重大な変化に対して解剖を加え, 克明な記 録を残す義務を感ぜられたことと思う。ここにそれ が立派な報告となってあらわれたことについて，そ の労をねぎらわねばならない.

9 章からなるこの書の内容と執筆者を紹介してみ る.

第 1 章 近世期における八郎潟周辺農漁村 (半田 市太郎, 日本史専攻). 第 2 章 明治以降の八郎潟 湖岸農漁業 (北条 寿, 人文地理学専攻). 第 3 章 八郎潟干拓と周辺地域の社会変動 (片野健吉, 社会 学専攻). 第 4 章 八郎潟湖岸農漁民の意識 (佐藤 怜, 心理学専攻). 第 5 章 八郎潟湖岸農漁村にお ける近代学校（户田金一，教育学専攻). 第 6 章 八郎潟湖岸農漁村における学校統合（藤原良毅, 教 育学専攻). 第 7 章 八郎潟湖岸農漁村に抽る青 年集団 (佐藤 守, 教育学専攻). 第 8 章.八郎潟 周辺地域における青少年問題 (佐藤，怜). 第 9 章 課題と展望 (半田市太郎).

主題は干拓によって生じた社会変動におかれてい る. その為に，第 $1 \cdot 2$ 章で近世以降における八郎 潟周辺の村落の変遷が説かれ, 第 3 章で干拓事業の 経過と周辺地域のそれに対する反応の大略が述べら れてある. 以上はこの書の主題からして，どちらか といえば前置きの役目を与えられているものかもし れない.干拓とそれに伴う社会変動の諸側面として， 第 4 章に湖岸農漁民の意識が，第 5 章と第 6 章に学 校の問題が，第 7 章で青年集団が，第 8 章で青少年 問題がとり上げられている.

勿論社会変動を明らかにしようというのであるか
ら，特に変動の生じる明治，そしてその前提となる 藩政期から説きおこすというのは当然で, 殆どの章 がそうである. 干拓以後に特に焦点をしぼった章は 第 $4 \cdot 7 \cdot 8$ の 3 章のようである. このあたりは苦心 の存する所であろうが, 必ずしも整然としているわ けではない.

湖岸の農漁業及び農漁村の変化は勿論とり上げら れており，第 $1-3$ 章の中に近世からの変化として 一貫して述べられているが，その他の側面はここに 扱われているものだけで充分であろろか. その様な 疑問は勿論残るが，主として交通と工業の展開を中 心として生ずる変動はどうしても広い地域の考察を 余儀なくさせるから，この八郎潟に関する研究では 自然に除外されざるを得なくなる．先づは不要とい ってもよいことであろうし，終章の課題と展望にお いて干拓の社会変動に及ぼす問題が改めて吟味され ている。

八郎潟については以前に，八郎潟総合学術調査会 によって「八郎潟の研究」秋田県教育委員会, 1965 というほぼ同様の巨大冊が出され，干拓以前の八郎 潟そのものを中心とした報告がある. 湖面の消失し た今日の記録と研究という意味で，今回の報告は特 に苦心要したことであろうし，又価值の甚だ高い ものがある.

付録として約 100 頁に余る資料，八郎潟干拓年表, 調査表もあり，本文中至るところに示された詳細な 分析と共に, 地理学にとってもこの種の問題に対す る有益な手がかりを与えられている.

共同研究のあり方という点でも多くの点で範を示 すものというべく，執筆者諸氏に深く敬意を表する.

(野間三郎)

Morisawa, M. E. : Streams, their dynamics and morphology. McGraw Hill, 175 p, 1968.

本書は著名な McGraw Hill 社で目下刊行中の Earth and Planetary Science Series の一巻として 出されたものである. 著者のモリサワは米国の 
Antioch College 助教授であり, Columbia 大学で定 量的地形学を專攻した Strahler 門下の女流地形学 者である. 名前の示す如く日系米人で1964年と 1966 年の 2 回にわたり来日したこともある. ほぼA 5 版 程度で本文は 170 ページにも充たない小冊子であり ながら，河川地形学で取り扱う領域，およびその諸 問題を初学者にもわかるように極めて平易に解説し ている点に著者の筆力の並々ならぬものを感じさせ る. 全体の構成は10章から成る. 各章のタイトルを 列記すると, 1 . 序論, 2 . 水文学, 3. 河流の水理学, 4. 土砂の流送，5. 河川の作用 (侵蝕), 6. 河川の 作用 (堆積)，7. 河床勾配と流路の形状，8. 平衡 勾配又は定常状態，9. 流路の平面形態，10. 河川 の流域となる.

序論で著者は河川地形学の発展の基礎となった水 理学者や物理学者の貢献を多としながらも, 流水に よって作られた地形の生成過程を説明すること，す なわち因果関係の究明が地形学者の任務であること を強調している.このような立場から河川の作用に 関する物理的法則についての知識が必要であるとし て, 水文学, 水理学の基本的原理を 2,3 章で説明 している. ただし，そこでは単なる公式や法則の羅 列に留らず，それらが地形変化にどのような意味を 有するかについて具体的に触れている点で水理学や
水文学プロパーの教科書とは異なったニュアンスを 持っている. 4，5，6章では河流の営なむ侵蝕, 運搬, 堆積の 3 作用をとり上げ，先ず基本的概念を 小項目として解説した後に従来の研究成果を簡潔に 紹介している. しかし, 現象面での指摘にの及留っ てその原因にふれていない箇所が散見され，紙数の 制約もあったのであろうが一寸惜しまれる。たとえ ば，浮流土砂濃度のピークが尖頭流量より先に出現 することなどは論理的にも証明されてるから付け加 えてほしかった７章では主に河床縦断形と横断形 の数学的表現, それらの形状に及ぼす諸因子の検討, それらの変形について述べ，これに関聯する平衡勾 配については別に 8 章で詳しく述べている．9章は 従来の定性的地形学において主分野を占めてきた河 川流路の平面的型態にふれているが，蛇行流路，網 状流路については最近の成果をとり込れてその原因 説明を試み，それらの流路形態と水理量との間の相 関関係にも言及している１0章の河川の流域は著者 の専門とする水系解析を中心に流域特性の相互関係， Horton の法則などを解説している.

全章を通じて図を豊富に使用し，写真も鮮明であ るが，好々に誤植や著者自身の不注意と思われる表 現の誤記がみられるのが玉に玷である.

（高山茂美）

\section{1. 単行本}

中国新聞呉支社編：呉港 251 p. 1968. 2 .

\section{2. 定期刊行物}

人文地理 20 巻 4 号 1968.8 .

史林 51 巻 3 号 1968. 5.

日米フォーラム 14 巻 9 号 1968. 9 .

自然科学と博物館 35 巻 $9 \sim 10$ 号 1968. 9 .

天文月報 61 巻 9 号 1968. 8 .

日本の科学と技術 9 巻 9 号 1968. 9 .

防災科学技術 5 号 1968. 8 .

工業立地 7 巻 9 号 1968.9.

籢井 8 月号 1968.8.

考古学雑誌 54 巻 1 号 1968. 6.

最近の抢もな人口統計 17 号 1968. 6.

人口問題研究 106 号 1968. 4.

農業経済研究 40 巻 2 号 1968. 9.

資源調查所資料（洪水文献集） 1 号 1968. 7 .
科学技術庁資源調査会報告 43 号 1968. 1.

埼玉大紀要 15 巻 1967 1968. 3.

埼玉大紀要 3 巻 1967 1968. 3 .

立正大文学部論叢 31 号 1968. 7.

The Geographical Journal, Vol. 134, Part 2, The Royal Geographical Society, June, 1968.

Boletin de la Sociedad Geografica de Lima, Tom LXXXVI, Enero-Diciembre, 1967.

Geologiya i Geofizika, 5, 6, 1968.

Seriya Geograficheskaya, No. 4, Izuestiya Akademii Nauk SSSR, 1968.

Izvestiya Vsesoyuznogo Geograficheskogo Obshchestva, Tom 100, Vyp. 4, 1968.

Földrajzi Kozlemények, XVI (XCII) Kötet, 1 Szám, 1968.

Japanese Psychological Research, Vol. 10, No. 1, May, 1968. 
Bibliography of Floods and their Computation Japan, 1968, National Institute of Resources, Science and Technology Agency.

\section{3. 別刷その他}

窪田重治 : 愛媛県・東予新産業都市における工業生産の地 域構造とその現状について 地理教材の研究 第 6 集 1968.

石水照雄 : 日本の都市圈人口 1965 年都市圈別人口 1960 一65年都市圈別人口増加率 市政 17巻 8 号 1968.

石水照雄 : 本邦諸都市の機能分類に関する若干の考察 愛 媛大紀要 4 巻 4 号 1965. 12.

石水照雄 : 本邦主要都市に関する Rank-Size Rule の検 定 愛媛大紀要 5 巻 1 号 1966. 12.

石水照雄 : 都市化現象の本質とその分析 都市問題研究 20 巻 1 号 1968. 1.

石水照雄 : J。ゴットマン〜メガロポリス〜 市政 17 巻 4 号 1968. 4
佐伯岩男：広島市産業の動向 広島市総合計画策定に関す る基礎的事項の調査報告 1968 .

福岡県林業試験場 : 福岡県下矢部川流域周辺林地生産力分 布図 1968. 3。

福岡県林業試験場：地力の面からみた造林技術の経済的な 評価例（福岡県下のスギ林）（普及資料） 1968. 3.

国立国会図書館：逐次刊行物目録 41 年版 1968. 5 .

Institut d'Economie Appliquée : Étude Sommaire de la Croissance des Arbres du District de Happy Valley, Labrador, Canada (Août-Septembre, 1966), Montréal, Mai, 1968.

Institut d'Économie Appliquée : Rapport du Centre de Recherches Arctiques pour L'Année 1966, Montréal, Canada.

Teruo Ishimizu : Geographic Analyses of City Functions in Japan, Reprinted from the "Japanese Geography 1966-its recent trends”, August, 1966.

\section{学 界 消 息}

\section{本学会関係}

評議員会 昭和 43 年 10 月 6 日 18 時30分 21時, 鳥取市白鬼荘（公立学校共済保養所）に打いて開催. 木内会長の挨拶の後，議長に米倉二郎君を選出，書 記を榧根 勇君に依頼した.ついで議題に入り，つ ぎのような報告および審議が行なわれた．1．会務 報告 1） 大学地理学研究強化委員会報告. 本誌 9 月号の学界消息欄にすでに報告しように，本委員会 委員を 8 月上旬に依嘱しましたが，44年度予算概算 要求の時期が切迫したので，常任委員会として，8 月26日文部省大学学術局長, 同審議官, 大学課, 教 職員養成課にそれぞれ「教育系大学における地理学 の実験学科目化」についての要望を行なった. その 内容は本誌10月号学界消息欄に報告した通りで，こ の報告は了承された．2）学会将来計画検討委員 会報告. 本年春の総会において承認された本委員会 について，その設置の主旨と委員名を報告し，第 1 回委員会の状況を主査矢沢大二君から説明され，了 承された. 3）研究委員会報告. 評議員会に対す る研究委員会の報告を予め文書で求めていたので, これを回覽して報告に換えた．地理学と教育に関す る研究委員会については主査尾留川正平君から, そ の組織の方針と組織の準備中であることが報告され，
了承された。つぎに，三つの研究委員会の報告を掲 載する。

＜都市地理研究委員会報告＞（主查・山鹿誠次） 1968年 6 月 1 日発足， 2 度の準備委員会で活動方針 などの原案を立て，地理学評論誌上などを通じ，都 市地理関係分野に関心ある会員への呼びかけを行な った。第 1 回集会 7 月 6 日（土） 東京工業高 校図書室で開催. 経過報告，組織および活動方針に ついて討議. 終って K. Philbrick（西オンタリオ大 学) の TIME-SPACE-DATA-BANK についての 講演を聞く。第 2 回集会 9 月 7 日（土）駒沢 大学会館で開催. 稲永幸男（関東電気通信局）：首 都圈における人口からみた都市化について，小金永 司（川崎市電子記録課長）：都市行政とコンピュー ターの 2 報告を聞き, 都市研究におけりるンピュー タ一利用の問題について討論した.なお，第 3 回集 会を10月 6 日（日）鳥取市白鬼荘，第 4 回集会を 10 月26日（土）お茶の水女子大学で行なう予定である. <計量地理学研究委員会報告 $>$ (主査・上野福男) 第 1 回の研究委員会を 7 月 11 日に開き（会場, 駒沢 大学)，当委員会の基本的活動方針を，1. 計量地理 学の本質と方法論の研究推進, 2. 計量地理学への 認識の拡大と普及, 3. 研究物の発表, 出版とテキ ストの作製，4. 他の学会（他の研究委員会をふく 
む）との協力， 5 . 委員の拡充と上述活動の実行方 法, 等について討議した. 第 2 回研究委員会を 9 月 14 日に開いた（会場青山学院大学）.三橋節子(Carleton Univ.), 奥野隆史, 山口岳志の三氏からシカ ゴ大学における計量的研究, 計量地理学とデータ等 に関する報告をききこれを中心にして討論した 第 3 回研究委員会を鳥取大学の機に開くに当っての 実行案を検討，確認した。この会合において在京委 員できめた活動方針について, 参加者からの批判, 積極的協力をうるよう努めることにした. <農業地理学研究委員会> (主査・白浜兵三) 1968年 7 月13日18名の発起人をもって結成の申請が なされたこの委員会は，7月26日常任委員会の承認 を経て発足した. 主查には明治大学渡辺 操君が推 されたが，その台湾・沖繩出張からの帰任を待って 9 月 21 日東京および周辺在住の有志が明治大学に参 集し，10月 6 日に予定された鳥取での委員会のため の打合わせ会を開き，次の諸点を議した，鳥取では 江波戸 昭・大貫 俊・白浜兵三の 3 君が会の活動 方向について提案すること，できるだけ多くの参加 者を得て44年度末までには成果を印刷に付すること ができるよう努力すること.なお会の活動目標とし ては, 日本の農業または農業地域に関する従来の研 究成果を集約しながら今後の農業地理学の在り方を 探究すること, 激変しつつある現代の日本農業を把 握する新しい方法を考究すること, 日本農業の国際 比較を試みること, 外国における農業地理学研究の 動向を把握することなどがあげられたが，一切は鳥 取で委員会の議に委ねることが諒解された。

4）その他「文部省科学研究費補助金の配分にか かる専門分科について」の文部省の試案について, 日本地理学会として要望書を提出したことを報告, 了承された. その内容の詳細については, 本誌11月 号学界消息欄を参照されたい. 2 . 審議事項 1) 1969年度春季・秋季学術大会の件, 1969年春季学術 大会はさきに, 東京教育大学で開催されることを決 定したが，現在の学園紛争解除の見透しがつかない ので, 都内の他の大学か, 大学以外の会場の選定に つてて検討した結果を集会委員長からはかられ，意 見を求められた. 東教大以外の大学として找茶の水 女子大，立教大などを検討したが，いずれも，1969 年度は都合が悪い状態であった．そこで大学以外の 会場として大学セミナーハウスを候補として議題と
し，配置図等の資料を配布して検討した．その結果， 大きい会場が少ないこと，距離的に遠いことなどの 難点が指摘されたが，そのような場所で大会を開く 試みも行なうべきである等の意見が出された. 結論 として, 常任委員会で早急にさらに検討することに なった，秋季大会々場も未定であるが，地方選出の 評議員との連絡をとり，なお検討することとした.

2）特別出版物に関する件. 1966年に Special publication No. 1 として, “Japanese Geography 1966, its recent trends.” が出版されているが, 最近, 外 国からの要求が多く，No.2についてもそのリス卜 を送付するようとの要請が多数にのぼる現状である. このような点も考慮して, 欧文の特別出版（さしあ たって No. 2) の出版についての可否等について意 見の交換を行なった.これらの意見の中には, 会計 的な措置との関連でその可否を検討すべきこと, 出 版を希望するが，会計的な裏付を必要とすることな ど挙げられた，そのほか，現在の日本地理学会の会 員構成からみて, 欧文の特別出版物は会員の負担と なるから一概に出版の方向に持って行くことは考え ものであるとの意見，また，会員構成の現状にとら われていては，学会は何もよい仕事が出来ないから 積極的に進めるべきであるとの意見, No. 1 の出版 の時に当時の執行部は No. 2 を出版することを約束 しているから出版すべきであるとの意見などが出さ れた. 結局, 会計的な検討を行ない, 常任委員会で さらに考虑することになった．3）昭和44年度科 学研究費の配分に関する学会の態度について. 常任 委員会は, 「日本学術会議第 50 回総会文部省科学研 究費補助金の配分に関する決定事項」を資料として 配布し，これに対して日本地理学会はどのように考 えるべきかについて意見を求めた. 種々討議の結果, 昭和44年度以降については, 日本学術会議の上記の 決定事項を支持する意見が大勢であった．評議員会 終了後, 渡辺 光会員から地理学研究連絡委員会の 報告があった. 出席者 木内信蔵会長, 有末武 夫, 石井素介, 井関弘太郎, 伊藤郷平, 上野福男, 岡本次郎, 織田武雄, 貝塚塽平, 籠瀬良明, 鴨沢 膂, 幸田清喜, 清水馨八郎, 谷岡武雄, 土井仙吉, 中野尊正, 西村嘉助, 能 登志雄, 尾留川正平, 福 井英一郎, 正井泰夫, 町田 貞, 矢沢大二, 山鹿誠 次, 吉川虎雄, 米倉二郎, 渡辺 光, 各評議員, 西 川 治, 市川正巳各常任委員, 榧根庶務委員. 
学会将来計画検討委員会 10 月 21 日 午後 5 時 30 分から東京地学協会において開催, 主として日本地 理学会の会員構成などについて審議が行なわれた。

都市地理研究委員会第 4 回集会 10 月26日（土） 13. 30 17. 30, 打茶の水女子大学において開催, 出 席者34名．まず，高橋伸夫氏(東京教育大学大学院) 他による「清水市に打ける都市化の展開」の研究発 表と山口岳志氏（駒沢大）の「都市機能の諸類型」 の研究発表があり，それぞれについて活発な討議が なされた.ひきつづき，山鹿誠次主査から第 3 回集 会で問題になった，来年度の「シンポジウム」につ いての説明があった. 1. 従来開催されたシンポ ジウム，2. 現在までに提案されたテーマ等が示 されたのち, テーマ, 運営方法, 開催後の出版物等 について会員から意見が出された。ほほぼ一致した点 として，シンポジウムには広いテーマをかかげ，そ のなかで絞った問題について討議してゆく方式をと り，テーマの試案として，「国土の都市化」(仮題) をとりあげ，そのうちとくに「日本のメガロポリス」 に焦点を合わせるということになった。 なお，これ に関して，主查と企画係に原案作製を委嘱すること とし, 次回集会以後, さらに審議を重ねてゆくこと になった。また，第 5 回集会は，12月7日（土）東 京都立大学において開催されることが決定されたの ち，閉会した.

会員消息 会員楠原直樹君 (東北大理助手) は本 年 4 月 1 日付で長崎大教養部助教授に昇進. 同二神 弘君（福岡教育大助教授）は10月 1 日付で富山大教 養部教授に昇進. 同大迫輝道君（岐皁経済大講師） は 10 月 1 日付で同大助教授に昇進. 同 井内 昇君 （東京都庁）は国会図書館に転勤された。同蒲原多 美子君（広島大大学院）はベルギ一政府の招きによ りリエージュ大学に一年間留学, 9 月 24 日出発. 同 高橋 正君（竜谷大）は同大の在外研究員としてフ ランスに 1 年間滞在のため 10 月 6 日出発. 同関口 武君（東京教育大）は, WMO 主催, WHO, CIB 共催で10月13日から同月26日にベルギー国ブラッセ ルで開かれた「都市気候学および建築気候学」のシ ンポジウムに出席した．その後ルーマニア科学学士 院の招待で, ブカレスト, ヤシ両市を訪問後, 11月 4 日に帰国した。

\section{他学会関係}

日本地理教育学会10月例会 10月19日（土）午 後 2 時から中教出版会議室で開かれ次の発表があっ た. 筑浦進一（一橋高）；最近の中近東.

富山地学会例会 10月19日（土） 13時30分から 富山大教育学部で開かれ次の報告, 研究発表があっ た. 藤森 勉; 日本地理学会報告, 藤井昭二; 日本 地質学会報告, 藤井昭二; 北太平洋の調査から帰っ て, 二神 弘; 現代地誌学への提言, 三鍋久雄・武 沢 正; ボルネオの調查から帰って.

日本国際地図学会例会 10 月26日（土） 13 時30 ～17時 農業土木会館で開かれつぎの発表があった 中條久雄（水路部）・鶴見英策（国土地理院）; 小笠 原・硫黄島をめぐる地図の話題.

歴史地理学会例会 10月26日（土）午後 2 時加 ら立教大学五号館で開かれ，次の発表があった．大 脇保彦; 和紙業の地域的展開.

経済地理学会例会 10月26日（土）13時30 16時 30分 明治大学11号館にて開かれ，つぎの発表があ った. 小池秀夫（早大）；神津島の漁業の特色，川 上 誠（都立墨田川高）; 新潟蒲原平野における水 稲生産の動向一水稲生産の「組織化」と「個別化」 をめぐって一.

第四紀学に和ける最近の進歩一境界領域シンポジ ウム— 10月26日（土） 10時～17時 日本学術会 議講堂に扎いて, 日本学術会議第四紀研連, 日本第 四紀学会, 日本地理学会, 日本地質学会, 日本人類 学会, 日本地球電磁気学会, 日本地球化学会の主催 のもとに開催され，つぎの研究発表が行なわれた。

日浦 勇 (大阪市立自然科学博物館); 生物地理と 第四紀，本庄 丕（北大・理）；超微生物による鮮 新・更新生の境界決定，小林国夫（信州大 - 理）; 第四紀初期の地磁気变動と絶対年代に関する最近の 知見，木越邦彦（学習院大・理）; 放射性同位元素 による年代測定法の進歩，芹沢長介（東北大・文）; 日本旧石器時代の諸問題, 柴崎達雄（資源研）; 第 四紀学における将来予測の問題一水文地質に例をと って一.

経済地理学会秋季東西合同例会 11 月 1 日（金） 10時 17時30分 京都大工学部電気総合館において 開催，つぎのシンポジウムが行なわれた．「海外地 域研究の成果と方法」，報告者：応地利明（名古屋 
工大), 大岩川和正 (アジア経研), 藪内芳彦 (大阪 市大), 米倉二郎 (広島大).

東洋音楽学会第 159 回例会 11 月 2 日（土） 14 時 17時 東京文化会館で開催, 楽器講座, 講演, 書籍紹介などが行なわれた。

第 5 回災害科学総合シンポジウム 11月11日(月) ・12日（火）それぞれ 9 時〜17時まで国立科学博 物館において, 文部省特定研究・災害科学総合研究 班の主催により, 日本地理学会を含む15学会の後援 によって開催され，75篇の研究発表が行なわれた。 その中で, 本会会員の発表はつぎのようである. 石 井泰義（長崎大・教育）；昭和 42 年 7 月豪雨による 五島列島における炎害の概報, 浅井辰郎（お茶大・ 文教）；後水期に打けるU字谷壁の大崩壊について (アイスランドの例)，小林基夫（国土地理院）; 豪 雨による山地崩壊の反復性について一呉・六甲の事 例一, 羽田野誠一（国土地理院）；地すべり性大崩 壊と地形条件一和歌山県有田川上流の事例一, 中野 尊正・門村 浩・松田磐余（東京都立大・理）; 埋 没地形の復元と地盤災害への応用, 中村三郎 (防衛 大）；電気探査の結果からみた大網地すべり地の特 性.

第15回風に関するシンポジウム 11月18日（月） 9 時30分 18時 京都大・理・地球物理学教室に打 いて, 日本地理学会を含む 9 学会の共催で開催, 25 の研究発表と特別講演が行なわれた. この中で, 本 会会員の発表はつぎのようである. 吉野正敏（法政 大）; 関東平野の「おろし」について, 同 ; 空中写
真からみた屋敷森の示す卓越風向，河村 武（気象 庁東管）；日本の強風地域，岩崎 尚（園芸試）; 静岡県柑橘試験場気象改良工法の風洞模型実験.

研究船淡青丸の共同利用申込につんての和知らせ 東京大学海洋研究所長西脇昌治氏から, 本学会宛 につぎのお知らせが参りました。

昭和44年度研究船淡青丸の共同利用申し込2の受 付を下記により開始いたしますから，貴所属関係各 位に周知方よろしくお取り計らい願います。

記

申込資格 : 海洋の基礎的研究を行なうもので原則 として，大学その他の機関に勤務する ものおよび大学院学生等とする.

申込期限 : 昭和 43 年 12 月 15 日

申込書類：研究船利用申込書 1 通 承諾書（大学院学生の場合は推薦書）

略歴書 1 通

申 込 先: 東京都中野区南台 $1-15-1$

東京大学海洋研究所

採否の決定 : 昭和44年 1 月中旬

用紙ご入用の向は，当所共同利用掛 宛その旨抢知らせ下さい。

なお，昭和 44 年度当昨年と同様特定海域の研究航 海は設けないことになりましたのでご了知願います。 おって研究船白鳳丸の共同利用申し込みのご通知は 近日中別途送付いたしますので申し添えます。 


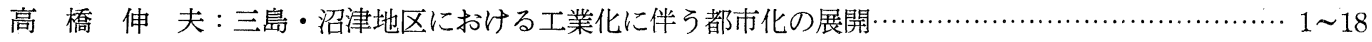

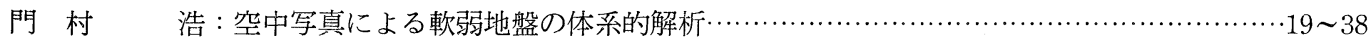

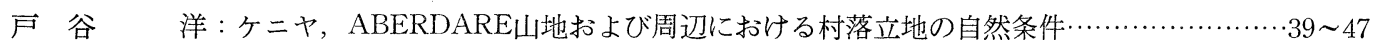

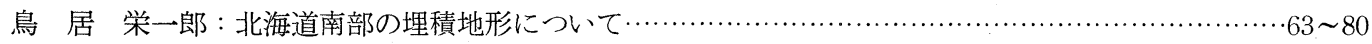

水 津 一 朗 : 古代ライン地溝帯に抢ける国府・キヴィタス・種族国家一古代における

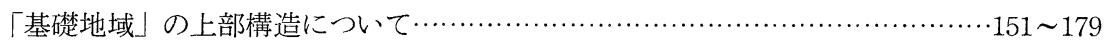

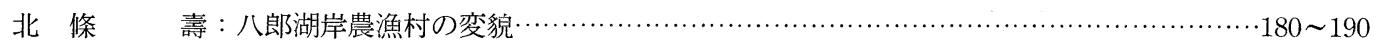

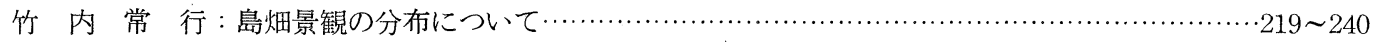

町田 洋・森山昭雄 : 大璣丘陵の tephrochronology とそれにもとづく富士および箱根火山の活動史 $\cdots 241 \sim 257$

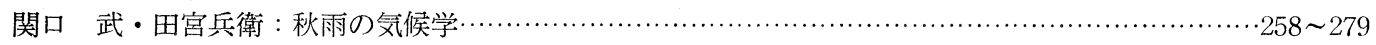

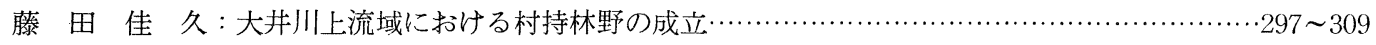

山 本 茂: 清水地区における造船業の下請利用一造船独占企業からみた場合………………310 321

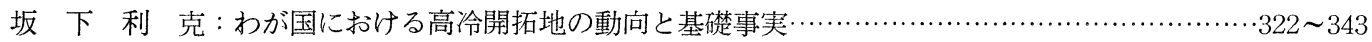

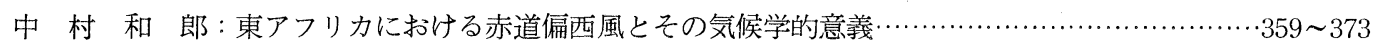

中野尊正・門村 浩・松田磐余 : 東京低地の埋没地形と地盤沈下……………………………...427 449

木内四郎兵衛・岩下茂子 : 利根川下流域における地下水一特に小見川・佐原・鹿島地域における

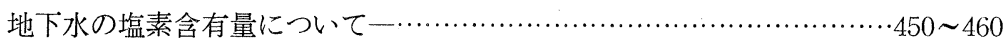

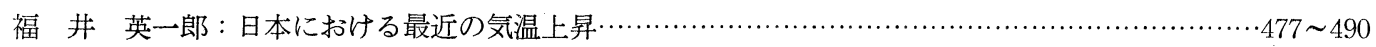

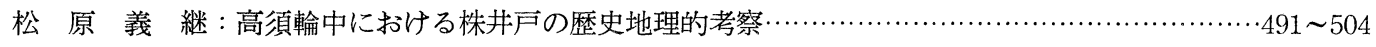

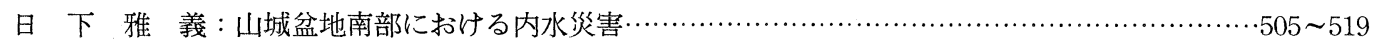

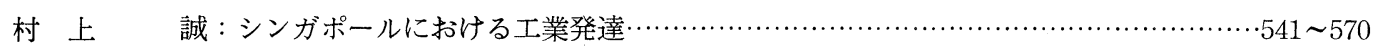

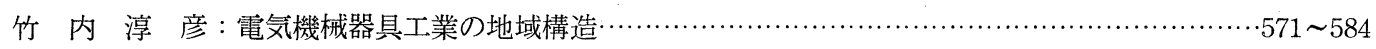

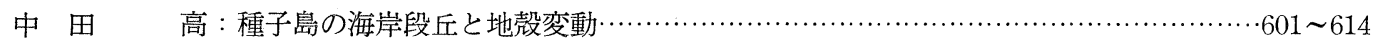

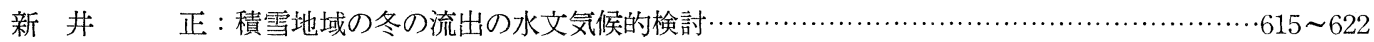

斎 藤 功：群馬県東南部における酪農地域の形成——東京集乳圈の拡大に関連して——……623 640

上 田 洋 行：山間盆地の地形面と条里に関する歴史地理学的研究………………………....657 673

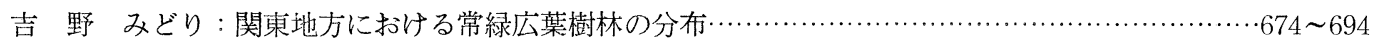

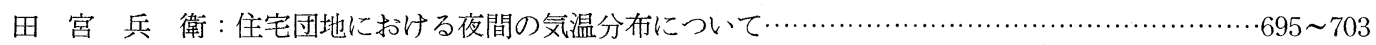

吉 野 正 敏 : 東アジアの夏型気圧配置の出現状態抢よびその異常と気温分布………................ $721 \sim 731$

三 浦 修: 海岸段丘からみた三陸リアス海岸の発達………....................................... $732 \sim 747$

堀 川㑆：昭和 34 年，41年に㧊ける 6 (7) 大都市の人口移動の統計的考察……................748 760

\section{研究ノート}

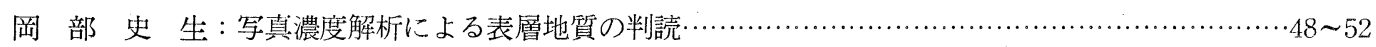

籠 瀬 良 明：中世城館の調査と豪族屋敷村一一刮目すべき二つの近業を中心として

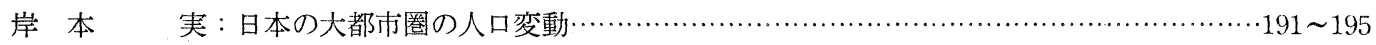

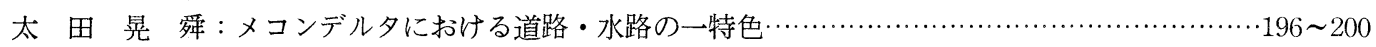

岡部史生・門脇和博・丸田英明：静岡県田子ノ浦港周辺の地下水塩水化現象……......................201 206

平 野 昌 繁：斜面形と表層物質の関連性についての一考察………………………............280 284

松 田 磐 余：濃尾平野における空中写真による土質判読……………………………………2. 285 290

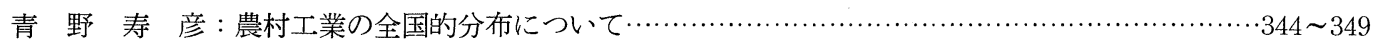

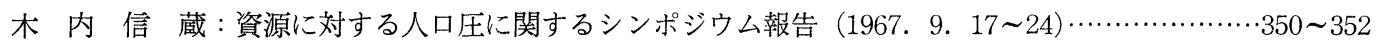


田辺裕：フランスの地方大学出版地理学誌

$461 \sim 464$

丸田 英 明: 襄磐梯泥流に関する若干の考察.

$\cdot 465 \sim 469$

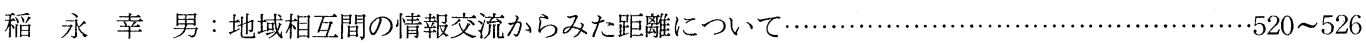

石 川 友 紀 : 海外移民と国内移住一一沖繩勝連村浜比嘉島比嘉の場合

$.585 \sim 593$

渡辺 光・福井英一郎・山本正三・正井泰夫：人類とその生態系（ユネスコ主催の生物資源の

合理的利用と保全に関する政府間専門家会議に対する報告書） $594 \sim 595$

三 野 与 吉：日本，主島の地形計測值…… $641 \sim 646$

守 屋 喜久夫 : 下末吉台地に多摩ローム層を発見……

$647 \sim 650$

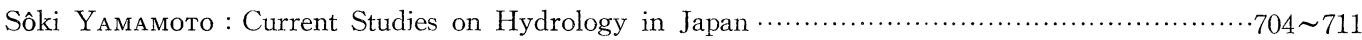

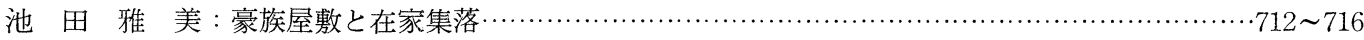

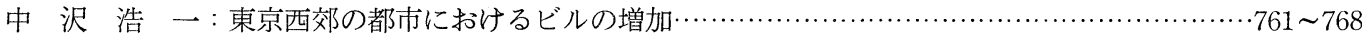

三 浦 鉄 郎：鳥海火山北斜面における開拓とその問題点……................................... 7699774

\section{書評}

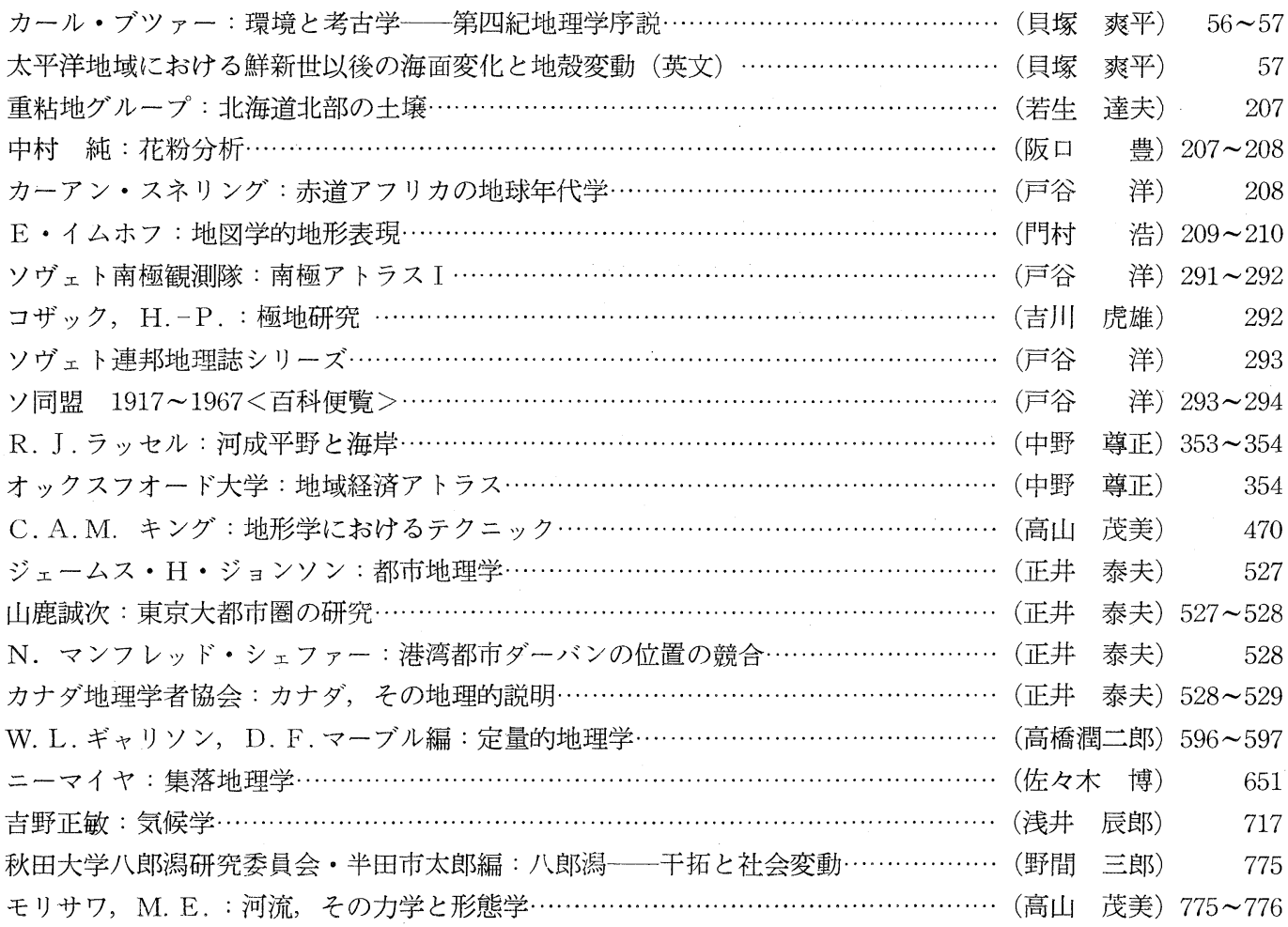

\section{抄 録}

グローテウォールド，サブレット：土地利用に与える輸入制限の影響

一英国と西ドイツの比較

（大石 堪山） 58 59

J.H. ウィンズロー：上昇海底谷（探究的な仮説）

(鳥居栄一郎) 354 355

\section{記 録}




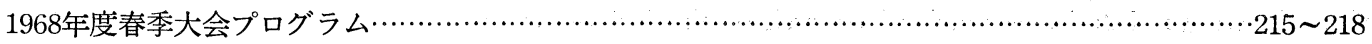

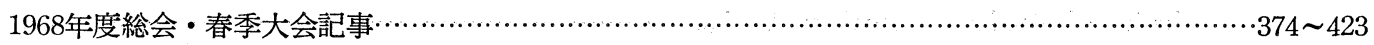

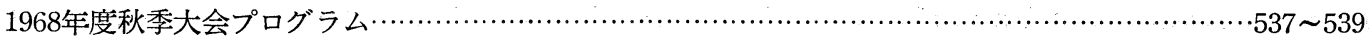

新着図書 $\cdots \cdots \cdots . . . . . .59 \sim 60,210 \sim 212,294,355 \sim 356,471 \sim 472,529 \sim 530,597 \sim 598,652 \sim 653,718$, $776 \sim 777$

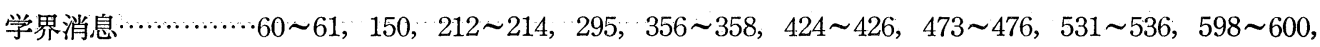
$653 \sim 655,718 \sim 720,777 \sim 780$

\section{Original Articles}

Nobuo TAKAHASH : Le progres de l' urbanisation avec l' industrialisation dans le

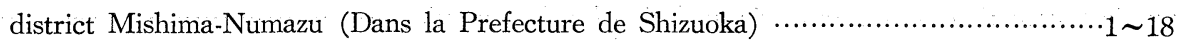

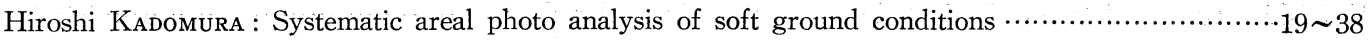

Hiroshi ToYa : On the location of native villages on and around the Aberdare Range, Kenya $\cdots \cdots \cdots \cdot 39 \sim 47$

Eiichiro Torir : The buried topography along the southern coast of Hokkaido $\cdots \cdots \cdots \cdots \cdots \cdots \cdots \cdots \cdots \cdots \cdots \cdots \cdots \cdots \cdots$

Ichiro SuIzu : Civitates und Stammstaaten im Vergleich mit japanischen

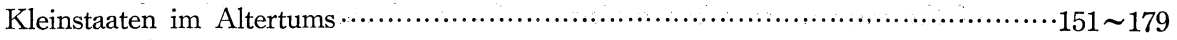

Hisashi Hōjōo: The change in the farming-fishing-villages on the coast of the Lake Hachiro-gata $\cdots 180 \sim 190$ Jögyō TAKEUCHI: On the distribution of "shima-batake" (island-like or

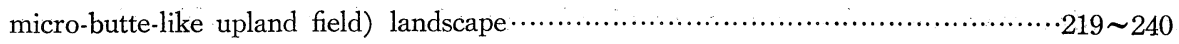

Hiroshi Machida, Akio Moriyama : The development of Mt. Fuji and Mt. Hakone volcanoes analysed from the tephrochronological study in the Ōoiso Hills $\cdots \cdots \cdots \cdots \cdot 241 \sim 257$

Takeshi Sekiguchi, Hyōe, TAmiya : A climatology of Autumnal rains in Japan …..................258 259

Yoshihisa Fujita: The establishment of village-holding forest land in the upper basin of River Ohi, Shizuoka Prefecture

Shigeru Yамамото: Some regional characteristics of subcontract system in Japanese shipbuilding industry illustrated in the Shimizu area, Shizuoka Prefecture …........310 321

Toshikatsu Sakashita : High and cool reclaimed land in Japan - trend and basic facts_...........322 343

Kazuo NaKamura : Equatorial westerlies over East Africa and their climatological significance $\cdots \cdots . .359 \sim 373$

Takamasa Nakano, Hiroshi Kadomura, Iware Marsuda : Buried landforms and ground subsidence in the Tokyo lowland $427 \sim 449$

Shiroheie Kivchi, Shigeko Iwashita : The distribution of chlorine content in the groundwater in the lower basin of the Tone River, concerning Omigawa,

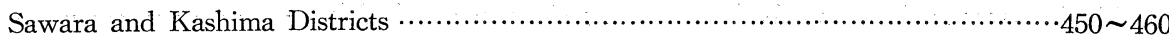

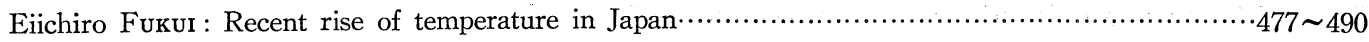

Yoshitsugu Matsubara: On the development of “Kabu-Ido", authorized artesian

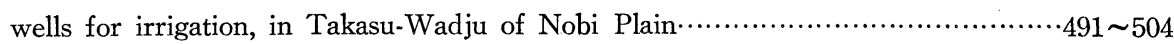

Masayoshi KusAKa : Inundation disasters in the lowland of southern Yamashiro …................5 505 519

Makoto Murakami : Geographical analysis of the industrialization in Shingapore …................541 5 570

Atsuhiko TAKeUchi : Regional structure of the electrical machinery industry in the Keihin area $\cdots 571 \sim 584$

Takashi NAKata: The coastal terraces of the Tane-ga-shima island and the mode of its crustal movement

Tadashi Arai : Hydro-climatological study on the mid-winter runoff from the

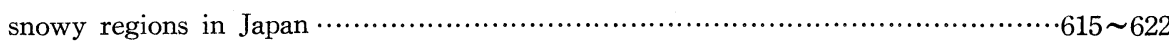

Isao SAITo : Forming process of dairy region in the southeastern Gunma Prefecture $\cdots \cdots \cdots \cdots \cdots \cdots \cdot 623 \sim 640$ 
Hiroyuki UEDA : Historico-geographical research on the Jori-system in the

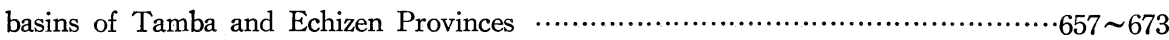

Midori T. Yoshino: Distribution of evergreen broad-leaved forests in Kantō district, Japan ……6674 694

Hyoe Tamiya : Night temperature distribution in a New-Town, western suburbs of Tokyo $\cdots \cdots \cdots \cdot 695 \sim 703$

Masatoshi M. Yoshino: Summer pressure pattern and temperature distribution in

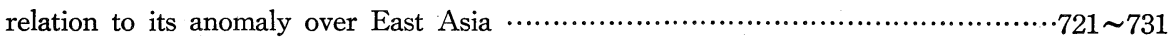

Osamu Mivra : Rias coast and coastal terraces of Sanriku, Northeastern Japan .....................732 7477

Tadashi Horikawa : A statistical approach to migration to and from the six large cities $\cdots \cdots \cdots \cdots \cdot \cdots \cdot \cdots 48 \sim 760$

\section{Miscellaneous Notes}

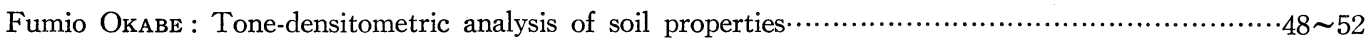

Yoshiaki KAGose: Notes on the 'gōzoku' settlement in medieval Japan ............................5 53 55

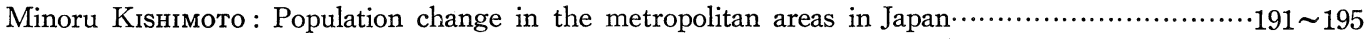

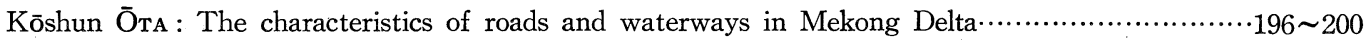

Fumio Okabe, Kazuhiro Kadowaki, Hideaki Maruta: The salt-water encroachment

of the ground-water in the vicinity of port of Tagonoura, Shizuoka

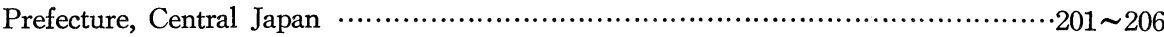

Masashige Hrrano: Some discussions on the relationship between slope and soil profiles …........280 284

Iware MATSUDA : Aerial photographic analysis of engineering soils in the Nöbi Plain $\cdots \cdots \cdots \cdots \cdots \cdots \cdots \cdot 285 \sim 290$

Toshihiko Aono: The distribution of cottage industries in Japan …..................................344 349

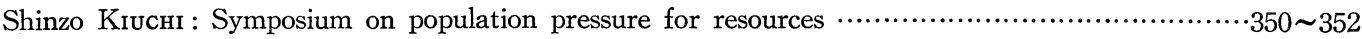

Hiroshi TANABE: Sur les revues géographiques publiées des universités provincielles en France $\cdots 461 \sim 464$

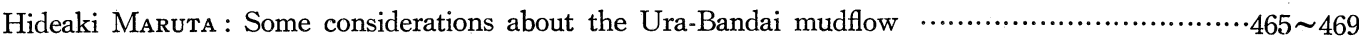

Sachio INANAgA : On the distance in terms of interregional communication information $\cdots \cdots \cdots \cdots \cdots \cdot 520 \sim 526$

Tomonori IsHikawa : Outside emigration and internal migration

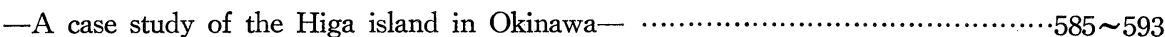

Akira Watanabe, Eiichiro Funui, Shōzo Yamamoto, Yasuo Masai : Man and his ecosystems $\cdots \cdots \cdot 594 \sim 595$

Yokichi Mino: Some measurements of geomorphic elements in the main islands of Japan...........641 646

Kikuo Moriya : Discovery of the Tama volcanic ash deposited at the

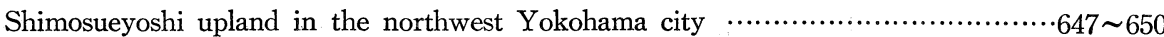

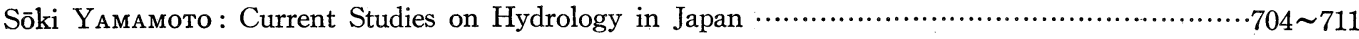

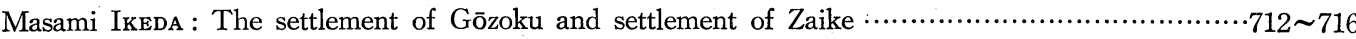

Kōichi NaKazawa : Fire-proof buildings in the cities, west of Tokyo …........................761 768

Tetsurō MiURA : The reclamation on the northern slope of Chōkai volcano and that problem points

$769 \sim 774$ 
会 告

日本地理 学会

12 月例会の和知らせ

下記のとおり，12 月例会を開きますので，ふるって御参集下さい．

1. 日時 1968 年 12 月 14 日（土） $13: 30 \sim$

2. 会場 学士会館本郷分室 6 号室 (赤門隣)

3. 発表 鈴木秀夫（東京大）：エチオピアの気候 付スライドによるエチオピア概観

4. 要旨 毎日の観測值にもとづいてエチオピアの天候推移とその原因を明らかにした。従来の知見と異なる 主な点は，秋に第三雨季のあること，I T Cによる降雨に 2 型式あること，大雨季に中休みがあることなど である．風景と地形の組み合わせで，エチオピアはいくつかの判然と異った自然地域に分かたれ，それぞれ 異なった生活様式を持っている.スライドを用いながらこれを説明する.

\section{都市地理研究委員会の和知らせ}

下記の通り第 5 回集会を開きますのでご参会下さい.

1）日時 12 月 7 日(土) $13.30 \sim 17.00$

2）場所 東京都立大学理学部地理学教室（梁沢校舎）涉谷より田園調布行バス（真中経由）八雲町下車

3）議題 清水鳘八郎・服部銈二郎：ソ連・北欧の都市と社会（スライド使用） 


\section{投禞 規 定}

1. 投稿の原則 原稿は，その内容が日本の地理学界における代表的学術誌の記事としてふさわしいものであ ること. 投稿者は，特別の場合をのぞき，日本地理学会会員に限る.

2. 原稿の採否は，編集專門委員会の議にもとういて，常任委員会がこれを決定する.

3. 原稿の種類は，論説，研究ノート，書評，抄録，学界消息などとする.

諭説は，その長短にかかわらず，オリジナルの研究成果をまとめたもので，本会その他の研究集会で十分 な討諓をへたものであることを原則とする.

研究ノートは, 研究の中間報告・予報, 本会誌に揭載された諭説・研究ノートなどに対する批判・反論, 地理学の全体あるいはある分野に関する研究成果などを総合的にまとめたものなどである.

書評は，地理学関係の図書についての紹介・批評であり，抄録は地理学関係の論文について行う. 学界消息は，本会関係その他の地理学界に関係する記事である.

4. 投稿原稿は，本会所定の原稿用紙に書くこと. 原稿用紙は，投稿題目，所要枚数を明記して本会事務所に 請求すれば実費にて送付する.

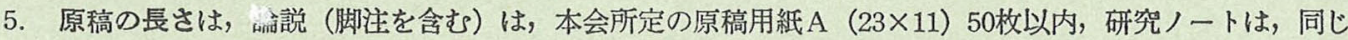
く 20 枚以内，書評は，同しく 10 枚以内，抄録は 5 枚以内程度とする. また，図表あわせて刷上り，論説 は14頁，研究ノートは 7 頁を限度とし，超過分については 1 頁単位で実費を徵収する．上記の制限をこえ る時には，あらかじめ文書にて編集専門委員会の承諾を求めるものとする.

6. 論説には，400字以内の摘要， 1,500 2,000 語程度の欧文要旨とそのもととなった和文をそえる. 研究 一トにはかならずしも欧文要旨をつける必要はないが，つける場合には 500 語程度以内のものとする.

7. 原稿は，本会所定の送付状に所要事項を記入のうえ，本会事務室内編集専門委員会あて，書留で送ること． 到着した原稿については，編集専門委員会が投稿者あてに，原稿の到着した旨を連絡して，受領書にかえ るものとする.

8. 揭載原稿は，著者に返送しない。ただし写真などとくに返送を希望するものについては，その旨をあらか ヒめ文書にて申出ること.

9. 論説・研究ノートは，投稿者の負担において，原則として 100 部これをこえる場合には 100 部を単位と して別刷をつくることができる.

10. 以上の規定は，1967 年 5 月 1 日以降受理の投稿に対して適用する.

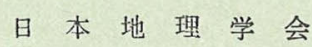

\begin{tabular}{|c|c|c|c|}
\hline 地理学評論 & $\begin{array}{c}\text { 第 } 41 \text { 巻 第 } 12 \text { 号 } \\
1968 \text { 年 } 12 \text { 月 } 1 \text { 日発行 }\end{array}$ & 印刷龍 & 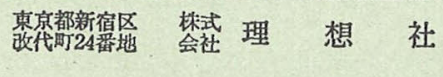 \\
\hline & $\begin{array}{l}\text { 東京都文京区本郷 } 7 \text { 丁目 } 3 \text { 番 } 1 \text { 号 } \\
\text { 東京大学理学部 地理学教室内 }\end{array}$ & 発売所 & 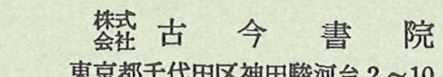 \\
\hline 編集発行者 & 日 本 地 理 学 会 & & 振替東京 35340 番 茜話 $(291) 2757$ \\
\hline $\begin{array}{c}\text { 郵便番号 } \\
113\end{array}$ & 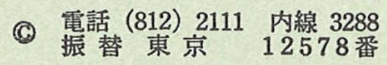 & & 定価 280 円 送料 12 円 \\
\hline
\end{tabular}

